\title{
PENERAPAN TEKNIK BERMAIN PERAN BIMBINGAN KELOMPOK UNTUK MENINGKATKAN KOMUNIKASI INTERPERSONAL SISWA KELAS X SMA PESANTREN MODERN PALEMBANG
}

\author{
Risma Yudata \\ Email: yudatarisma22@gmail.com \\ SMA PESANTREN MODERN PALEMBANG
}

\begin{abstract}
ABSTRAK
Tujuan diadakannya penelitian ini untuk mengetahui penerapan tehnik bermain peran bimbingan kelompok untuk meningkatkan komunikasi interpersonal siswa kelas X di SMA Pesantren Modern Palembang dan untuk mengetahui ada dan tidaknya peningkatan komunikasi interpersonal siswa sesudah diberikan layanan bimbingan kelompok dengan menggunakan teknik bermain peran.Metode penelitian ekperimen ini, peneliti menggunakan dengan bentuk pre-experimental design 'One-group pre-test dan post-test'. Dengan teknik pengumpulan data menggunakan angket, observasi, dokumentasi. Hasil yang diperoleh dalam penelitian ini menunjukan bahwa adanya komunikasi interpersonal siswa dapat ditingkatkan dengan menggunakan bimbingan kelompok dan menggunakan teknik bermain peran. Hal ini di tunjukan dari hasil data dengan menggunakan uji Wilcoxon. Hasil pre-test dan post-test yang di peroleh Zoutput $\geq$ Ztabel (-7.304) maka Ho ditolak dan Ha diterima yang berarti untuk meningkatakan komunikasi interpersonal siswa dapat menggunakan bimbingan kelompok dengan teknik bermain peran kepada siswa.
\end{abstract}

Kata Kunci : Bimbingan Kelompok, Teknik Bermain Peran, Komunikasi Interpersonal

\section{APPLICATION OF THE GROUP GUIDANCE ROLE-PLAYING TECHNIGUES TO IMPROVE THE SCHOOL'S INTERPERSONAL COMMUNICATION OF MODERN ATTENDING SENIOR HIGH SCHOOL}

\begin{abstract}
The purpose of this study is to learn the application of the group's guiding roleplaying techniques to improve the class $x$ interpersonal communication at modern boarding school and to see if there is a and no improvement in student interpersonal communication after the group's guidance services have been given using role-playing techniques. This experimental study method, researchers have adopted a pre-programmed design 'one-group pre-test and post-test'. With data collection techniques using angkets, observations,
\end{abstract}


documentation. The results obtained in the study suggest that any interpersonal communication of the students can be improved by using group guidance and role-playing techniques. It shows you the data results using the wilcoxon test. Pre-test and post-test obtained by zoutput > ztables (-7304) so ho was rejected and ha received which is meant to improve say that student interpersonal communication can use group guidance with role playing techniques.

\section{Keywords:Group Guidance, Role-playing Techniques, Interpersonal Communication}

\section{PENDAHULUAN}

Komunikasi interpersonal ini merupakan bagian dari kehidupan manusia, namun masih banyak masalah yang timbul dan berkenaan dengan komunikasi, misalnya di lingkungan sekolah siswa di tuntut untuk mampu berkomunikasi secara baik tetapi masih ada siswa yang lebih suka menyendiri, tidak mempunyai keterampilan sosial yang baik dengan lingkungan di sekolah, serta tidak suka mendengarkan pendapat orang lain.

Untuk meningkatkan kemampuan komunikasi interpersonal siswa, diperlukan dukungan dari semua pihak yang terlibat dengan siswa, terutama siswa itu sendiri. Selain itu peran guru bimbingan konseling juga sangat diperlukan untuk membantu siswa mengentaskan masalah terkait dengan komunikasi interpersonalnya. Salah satu jenis layanan bimbingan dan konseling yang dipandang tepat dalam membantu siswa untuk meningkatkan komunikasi interpersonal adalah melalui layanan bimbingan kelompok dengan menggunakan teknik bermain peran (role playing) yang mana layanan ini dilaksanakan dalam bentuk kelompok yang terdiri dari 8-15 orang anggota.

\section{LANDASAN TEORI}

Menurut Romlah (dalam wicaksono 2013:62) bermainan peran merupakan salah satu teknik yang telah diteliti oleh para ahli yang bekerja di bidang penyelenggaraan latihan-latihan. Para ahli telah membuktikan bahwa 
permainan peran merupakan tehknik yang bermutu. Para ahli psikologi prilaku menggunakan teknik tersebut untuk melatih ahli komunikasi atau ahli hubungan interpersonal dalam lingkungan pekerjaan. Pada saat ini permainan peran secara lebih luas telah diterima sebagai tehnik yang melatih berbagai macam hubungan interpersonal. Melalui layanan bimbingan kelompok teknik bermain peran di harapkan siswa akan dapat mengembangkan perasaan, pikiran, serta menghargai oranglain yang memiliki pendapat berbeda. Dan selain itu juga dapat menyelesaikan permasalahan yang dimiliki nya terkait komunikasi interpersonal.

Dapat di simpulkan dari uraian diatas, untuk meningkatkan komunikasi interpersonal siswa dapat digunakan bimbingan kelompok dengan menggunakan tehknik bermain peran karna dalam bimbingan kelompok tehnik bermain peran bermanfaat untuk kehidupan sehari-hari baik sebagai individu maupun sebagai pelajar, anggota masyarakat, serta dapat di pergunakan sebagai pengambilan keputusan dan berkomunikasi dengan baik di manapun siswa itu berada.

\section{METODE PENELITIAN}

Variabel Penelitian adalah segala suatu yang berbentuk apa saja yang ditetapkan oleh peneliti untuk dipelajari sehingga diperoleh informasi tentang hal tersebut. Kemudian ditarik kesimpulannya, (Sugiyono, 2009:38) pada penelitian ini terdapat 2 variabel yang terdiri dari :

1. Variabel bebas $(\mathrm{X})$ : Layanan bimbingan kelompok teknik bermain peran

2. Variabel terikat (Y) : Kemampuan komunikasi interpersonal siswa kelas $\mathrm{X}$ SMA Pesantren Modern.

Populasi dalam pennelitian ini terdiri dari 12 Laki-laki, 18 Perempuan yang berjumlah 30 orang siswa. Penelitian ini menggunakan Metode eksperimen, peneliti memilih menggunakan dengan bentuk pre-experimental 
Design 'One-Group Pretest dan Posttest'. Dalam pre-experimental Design 'One-Group Pretest dan Posttest' ,bahwa hasil perlakuan dapat diketahui lebih akurat, karena dapat memebandingkan dengan keadaan sebelum di beri perlakuan (Sugiyono, 2014:74).

\section{HASIL DAN PEMBAHASAN}

Hasil dalam penelitian diuraikan berdasarkan peneliti akan menyajikan hasil perbandingan pre-test dan post-test untuk melihat tingkat keberhasilan treatment. Sebelum melaksanakan kegiatan layanan bimbingan kelompok peneliti terlebih dahulu akan membagikan angket untuk mengetahui adanya komunikasi interpersonal rendah pada siswa di SMA Pesantren Modern Palembang.

Tabel 1. Hasil Pre-Test Dan Post-Test

\begin{tabular}{|c|c|c|c|c|}
\hline Kode & Prestest & Kriteria & Posttest & Kriteria \\
\hline $\mathrm{AF}$ & 103 & Tinggi & 122 & Tinggi \\
$\mathrm{DD}$ & 56 & Rendah & 80 & Sedang \\
\hline AP & 96 & Sedang & 110 & Tinggi \\
\hline BR & 48 & Rendah & 75 & Rendah \\
DS & 126 & Tinggi & 130 & Tinggi \\
\hline DA & 95 & Sedang & 112 & Tinggi \\
\hline DM & 73 & Rendah & 90 & Sedang \\
AY & 89 & Rendah & 105 & Tinggi \\
\hline DR & 64 & Rendah & 75 & Rendah \\
& \multicolumn{3}{|l|}{ Mean } & \multicolumn{2}{|c|}{ Mean } \\
\hline
\end{tabular}

Berdasarkan tabel sebelumnya dilihat dari hasil pre-test dan post-test bahwa sebelum melakukan bimbingan kelompok dengan menggunakan teknik bermain peran terdapat 5 siswa yang memiliki kriteria komunikasi interpersonal dengan hasil skor rendah yaitu 48-89, yang mendapat kriteria nilai sedang 9596, dan yang mendapatkankan kriteria nilai tinggi berjumlah 2 siswa dengan nilai pre-test130-120. Dapat dibedakan dengan setelah diberikan bimbingan 
kelompok dapat dilihat dari 2 siswa dengan kriteria nilai tinggi, meningkat menjadi 5 siswa dengan nilai post-tes 105-130.

\section{KESIMPULAN}

Berdasarkan hasil dari penelitian analisis data dan pembahasan dapat disimpulkan bahwa gambaran komunikasi interpersonal siswa kelas X SMA Pesantren Modern Palembang sebelum melakukan bimbingan kelompok dengan menggunakan teknik bermain peran menunjukkan kategori sedang. Hal ini bermakna bahwa komunikasi interpersonal siswa kelas X di SMA Pesantren Modern Palembang dikarnakan masih adanya siswa yang belum bisa menyampaikan pendapatnya saat sedang melakukan kegiatan belajar di dalam kelas. Hal ini terbukti dari hasil data dengan menggunakan uji Wilcoxon. Hasil pre-test dan post-test yang di peroleh Zoutput $\geq$ Ztabel (-7.304) maka Ho ditolak dan Ha diterima yang berarti untuk meningkatakn komunikasi interpersonal siswa dapat menggunakan bimbingan kelompok dengan teknik bermain peran

kepada siswa kelas X SMA Pesantren Modern Palembang tahun ajaran 2020/2021.

\section{DAFTAR PUSTAKA}

Abkin. 2013. Panduan umum bimbingan konseling. Jakarta.

Anwar, Y. 2018. Efektifitas teknik role playing dalam meningkatkan komunikasi siswa dan guru di SMPN 2 Kembang Tanjong.

Edi harapan , H. 2014. komunikasi antar pribadi . jakarta.

Gantina Komalasari. 2011. TEORI DAN TEKNIK KONSELING. KembangJakarta Barat 11610.

M. Ferdiansyah, M. 2015. DASAR PENELITIAN KUALITATIF. Bogor: Herya Media.

Muhammad budyatna, L. 2011. Teori Komunikasi Antar Pribadi. Jakarta.

Septiani, R. D. 2019. Pengaruh layanan bimbingan kelompok dengan teknik bermain peran terhadap kemampuan berkomunikasi interpersonal siswa.

Sugiono. 2009. Metode Penelitian Kuantitatif, Kualitatif. Jakarta.

Sugiyono. 2009. Metode Penelitian Kuantitatif, Kualitatif. Jakarta. 
Suharsimi, A. 1993. Prosedur Penelitian Suatu Pendekatan Praktik. Jakarta: Renika cipta.

Tohirinn, -E. 2013. BIMBINNGANN DANN KONSELING DI MADRASAH (BERBASIS INTEGRITAS). Jakarta: Rajawali.

Wahyu nila kanti, s. 2014. Efektifitas layanan bimbingan kelompok dengan teknik role playing untuk meningkatkan komunikasi interpersonal. Indonesia journal of guidance and counseling: theory and application, Issn 2252-6374.

Wicaksono. 2013. penerapan teknik bermain peran dalam bimbingan kelompok untuk meningkatkan kemapuan komunikasi interpersonal siswa kelas $\mathrm{X}$ Multimedia SMK Ikip Surabaya. journal mahasiswa bimbingan konseling, Vol1 No.1.

Wirda Hanim, A. E. 2017. Pengaruh Teknik Role Playing dalam bimbingan kelompok Terhadap. Pengaruh teknik role playing dalam bimbingan kelompok terhadap toleransi.

Wirda, \& Wirda Hanim, A. E. (n.d.). pengaruh teknik role playing dalam bimbingan kelompok terhadap toleransi pada peserta didik kelas $\mathrm{X}$ SMK Negri 26 Jakarta. 